International Journal of Business Management and Economic Review

Vol. 4, No. 02; 2021

ISSN: 2581-4664

\title{
THE EFFECT OF ORGANIZATIONAL CLIMATE AND ORGANIZATIONAL COMMITMENT ON ORGANIZATIONAL CITIZENSHIP BEHAVIOUR AND ITS IMPACT ON EMPLOYEE PERFORMANCE AT PIDIE JAYA REGIONAL SECRETARIAT OFFICE
}

\author{
Harmius,MukhlisYunus,SaidMusnadi \\ Management Department, UniversitasSyiah Kuala, Indonesia \\ http://doi.org/10.35409/IJBMER.2021.3242
}

\begin{abstract}
This study aims to measure the effect of organizational climate and organizational commitment on organizational citizenship behavior (OCB) and its impact on employee performance. The population was all employees of Pidie Jaya Regional Secretariat Office as one of the government institutions in Pidie Jaya District, Indonesia, as many as 221 employees consisting of 63 permanent employees and 158 contract employees. The sample in this study was determined by total population sampling where the entire population was used as the sample. Structural Equation Modeling (SEM) was used to analyze the effect of all the variables. The result shows that Organizational climate affects OCB; Organizational Commitment affects OCB; Organizational Climate does not affect Employee Performance; Organizational Commitment affects Employee Performance ; OCB affects Employee Performance; OCB fully mediates the influence of Organizational Climate on Employee Performance, and; OCB partially mediates the influence of Organizational Commitment on Employee Performance. The findings of this research can contribute to the development of knowledge, especially in the field of management on the object of government employees. This model of improving the performance of government employees can be relied on by making improvements to the organizational climate that will take advantage of OCB as a mediator in improving their performance, and strengthen organizational commitment that is able to influence their performance both directly and through OCB. Further researchers are advised to further develop government employee performance models like this by testing them with variables such as organizational culture and talent management.
\end{abstract}

Keyword: Organizational Climate, Organizational Commitment, Organizational Citizenship Behavior, Employee Performance.

\section{INTRODUCTION}

The Regional Secretariat of Pidie Jaya district, Indonesia, as one of the government organizations, is guided by the Qanun of the Pidie Jaya Regent No. 4/2016, about government institution formation in Pidie Jaya Government. The existence of public organizations as public servants that could respond to community development by determining an acceptable service vision. As a public organization, Pidie Jaya Government has an obligation to help the regent in 


\section{International Journal of Business Management and Economic Review}

Vol. 4, No. 02; 2021

ISSN: 2581-4664

formulating policies and coordinating regional offices, technical institutions, and regional Institutions.

As a main organizational instrument in Pidie Jaya, it is expected to be more responsive in facing the various demands for change, in other words, not only working with existing rules or guidelines or on the superior orders but also required to be creative and innovative in interpreting the rules according to the aspirations of the community (Muttaqin, Djumadi, \& Noor, 2013). Organizational performance is one of the parameters in measuring organizational goals, because it is a reflection of the organization's ability to manage and allocate its resources.

Human resources are required to provide a competitive advantage to reach optimal organizational performance. The competitive advantage can be seen from employee knowledge, skills, attitudes and work behavior that are directed at achieving organizational goals. The rapid development of technology, information and science place globalization in a strategic position which has a major influence on changes in systems and values in society, community organizations and also government organizations. Civil servants as elements of the public servants, have an important role in creating a civil society that obeys the law, has a modern, democratic, prosperous, just, and has morals that provide services fairly and equitably, maintaining national unity and integrity based on Pancasila and constitution.

Based on the previous survey, it can be seen that the employee performance quality at the secretariat office has not been optimal. The employees stated that their performance is not as expected. The factors that contribute to the underperformance of the Pidie Jaya secretariat office are quality and quantity of work, commitment, discipline and leadership. Even though other aspects have shown good performance, This institution still needs to work hard and smart by mobilizing all available resources to achieve organizational goals, both human resources, technology, facilities, infrastructure and a conducive work environment that can support the performance of employees in achieving better organizational performance output. Theoretically, an organization is a place for each member (individuals) to realize their needs through work (Mohammad, Habib, \& Alias, 2011). In an organization, its members try to work their best, interact with others harmoniously and build a sense of togetherness (mutualism symbiosis) between the organization and its members. If it can be realized, it will produce an organization with high progress (well progress). It will encourage employees to work optimally and even provide dedication beyond the main tasks and duties assigned to them. The behavior and attitudes of government officers who dedicate themselves exceed the theoretical demands of their duties related to Organizational Citizenship Behavior (OCB).

OCB is an extra behavior that is not part of an employee's formal obligations, but it supports the organization effectively (Robbins \& Judge, 2008). According to (Podsakoff, Ahearne, \& MacKenzie, 1997) the benefits of OCB for the organization are increasing the productivity of colleagues, improving the organizational human resources efficiency for productive purposes in coordinating activities between employees and groups. The OCB concept is very influential in organizational development. OCB continues to be developed and comes up with employee engagement theory. Employee engagement is a concept developed from positive psychology and positive organizational behavior (Albrecht, 2010). Employee Engagement is a feeling of passion from an employee/staff towards work, commitment to the organization and meaning without fatigue and the expectation of rewards in carrying out their work.

The initial survey result showed that employee engagement or OCB had not shown a high 


\section{International Journal of Business Management and Economic Review}

Vol. 4, No. 02; 2021

ISSN: 2581-4664

level of passion. Several respondents stated an increase in the extra roles inside and outside their work thus they could work more effective in achieving organizational goals, but this still could not be realized because some employees who did not obey the rules / low motivation, neglecting responsibility and efforts to work optimally.

The low OCB value at the office will have a negative impact on the organizational performance of the sub-district secretariat. To achieve the targets, it is necessary to have a better OCB. One of the ways to create OCB is through organizational climate (Haritha \& Subrahmanyam, 2013). (Haritha \& Subrahmanyam, 2013) stated that the organizational climate is the perceptions, feelings and attitudes of organization members regarding fundamental issues in the organization such as norms, values and culture that can influence individual behavior that can add positive or and negative value for organizational performance. Furthermore, the organizational climate is a combination of various aspects of the work environment that is accepted and felt directly or indirectly by employees which will determine the employee's behavior.

Organizational climate is one of the factors that affect work motivation and have an impact on employee performance, in order to all tasks achieved properly. If employees feel the conducive organizational climate in the organization, it means that the organizational climate is in accordance with the needs of employees in general which makes employees feel comfortable to work, a good organizational climate in the organization is developed according to the needs of employees, will leadconfidence in the organization and motivate them to make a positive contribution in achieving organizational goals. The climate in the organization will determine how employees carry out their duties and responsibilities according to procedures or not (Purwanti \& Nurhayati, 2016).

Organizational climate change has a strong influence, where organizational change for the better leads to the ability of organizational members to work as a team. If the organization pays attention and cares about employees, they will give constructive behaviors outside the organizational work requirements, likewise if the organization is able to provide a climate that is perceived positively by employees.

Besides organizational climate factors, organizational commitment factors can also affect $\mathrm{OCB}$ and have an impact on employee performance. Organizational commitment is the assurance of one's behavior towards the organization in the form of loyalty and achievement of the organization's vision and mission as well as the values and goals of the organization. Organizational commitment relates to the level of employee loyalty and emotional attachment to the organization. With a high commitment to the organization, the feeling of love for the organization will be greater and a sense of responsibility for organization achievement will become a priority for employees. Therefore, the organization will grow in accordance with the vision and mission of the organization. This is in line with the opinion (McShane \& Glinow, 2010) that organizational commitment is the most powerful influence, where people are highly motivated to carry it out, even when the source of motivation is no longer in the organization.

Employees who have a strong commitment to the organization will have the potential to improve performance both individually and in groups. Employees who have a high organizational commitment will volunteer their maximum efforts for the progress of the organization, such as trying to achieve organizational goals, maintaining organizational values and participating actively in advancing the organization. This organizational commitment is 


\section{International Journal of Business Management and Economic Review}

Vol. 4, No. 02; 2021

ISSN: 2581-4664

influenced if organization involvement proves to be a satisfying experience for the employees, it can provide opportunities to work better or generate opportunities to get a valuable Organizational Climate, It means that employee commitment toward the organization or organization affects their job satisfaction.

Based on the various explanations mentioned above, the authors were interested in conducting comprehensive research. This research focuses on the standard of work model of Pidie Jaya District Secretariat employees who experience inadequacy in organizational performance to achieve the goals. A lot of research has been done in examining the implementation of contingency theory, but mostly was done with a business and organizational perspective and very little is seen from public organizations such as this research. In addition, several previous studies also linked employee performance with $\mathrm{OCB}$, organizational climate and organizational commitment (Margaretha \& Wicaksana, 2020); (Aspan et al., 2019); (Iskandar, Hutagalung, \& Adawiyah, 2019); (Merentek, Adolfina, \& Trang, 2018); (Vijayabanu, Anand, Kumar, \& Therasa, 2017); (Chang, Tsai, \& Tsai, 2011)in a separate model, which will be combined in the hypothesis of this study.

\section{LITERATURE REVIEW}

\subsection{Employee Performance (EP)}

Performance is organizational behavior that is directly related to the production of goods or delivery of services (Buleleng, 2019). Performance is often thought of as the task achievement, where the term task comes from the thought of activities needed by workers (Gibson, Ivancevic, \& Konopaske, 2012). Performance includes aspects of business, loyalty, potential, leadership, and work morale. (Yukl, 2010) used the term proficiency which contains a broader meaning, where proficiency is seen from three aspects, namely: behaviors shown by a person at work, real results or outcomes achieved by workers, and assessments on factors such as motivation, commitment, initiative, leadership potential and work morale. Performance reflects how well and how precisely an individual meets the demands. Organizational performance information is very important to evaluate whether the work processes have been in line with the goals or not.(Wirawan, 2012) explained that 3 factors affect performance, namely:

a) Internal employee factors: factors from within the employee, from birth and factors obtained when he develops. For example: knowledge, skills, work ethic, work experience, job satisfaction and work motivation.

b) Organizational internal environmental factors: the condition of employees need support from organizations where they work. For example: support for the resources needed to carry out work, strategy, organizational commitment, management and compensation systems.

c) Organizational external environmental factors: circumstances, events or situations that occur in the external environment of the organization that affect employee performance. For example: the economic and financial crisis, inflation, lowered the nominal value of employee wages and salaries, which in turn reduced the purchasing power of employees.

Apart from those factors, OCB is also one of the factors that influence employee performance. According to (Takeuchi, Bolino, \& Lin, 2015) in their research, it stated that OCB is a valuable managerial tool for organizations, and has a positive effect on individual, group, and organizational performance. OCB is a behavior performed by an employee that exceeds formal work obligations, but has a good impact because it supports organizational effectiveness 


\section{International Journal of Business Management and Economic Review}

Vol. 4, No. 02; 2021

ISSN: 2581-4664

(Robbins \& Judge, 2014). Organizational success is not only determined by the behavior of employees who are determined according to their job (in role), but also the behavior outside their job description (extra-role) (Organ, 2015). OCB is an alternative to assessing employee performance in an organization with an informal assessment system. Several empirical facts show that organizations that have good OCB will also have better performance (Suzana, 2017). In general citizenship behavior refers to 3 main elements, namely: compliance, loyalty, and participation.

In addition, organizational commitment also affects employee performance. As stated by (Merentek et al., 2018) in their research, organizational commitment is the variable that has the most influence or the strongest influence on employee performance. This is also proven by the research (Paramita, 2018) which determines the effect of organizational climate (X) on employee performance (Y2).

Specifically, for State Civil Servants (ASN), the measurement of employee performance refers to the Indonesian Government Regulation Number 46 of 2011 concerning Assessment of Work Performance of Civil Servants which is divided into 2 (two) elements, namely:

1.ASN Job Goals (SKP).

It is a work plan and targets to be achieved by an ASN and carried out in a certain time. ASN's work objectives include several aspects:

a. Quantity is an amount of work achieved by an ASN person.

b. Quality is the quality of each work achieved by an ASN.

c. Time is the length of the process of each work achieved by an ASN.

d. Cost, the budget used for each work result by an ASN

2. Work Behavior

Attitude or action taken by an ASN that should or should not be carried out in accordance with the laws and regulations. The elements of work behavior include:

a. Service orientation

b. Integrity;

c. Commitment;

d. Discipline;

e. Cooperation; and

f. Leadership.

\subsection{Organizational Citizenship Behavior (OCB)}

According to (Aldag \& Reschke, 1997) Organizational Citizenship Behavior (OCB) is an individual's contribution in exceeding the demands of a role in the workplace. This OCB includes some behaviors including helping others, volunteering for extra tasks, obeying rules and procedures in the workplace. This behavior shows the value of employees which is a form of prosocial behavior, namely social behavior that is positive, constructive and helpful. Meanwhile, according to (Organ, 2015), OCB is the behavior of individuals who are free, not directly related to the reward system and can improve the organization's effectiveness. (Huang, Wang, \& Xie, 2014) stated that OCB behavior is a term used to identify employee behavior.

(Organ, Podsakoff, \& MacKenzie, 2006) stated that the benefits of OCB for an organization are as follows:

- Increase the productivity of managers and co-workers 


\section{International Journal of Business Management and Economic Review}

Vol. 4, No. 02; 2021

ISSN: 2581-4664

- Saves resources owned by management and the organization

- An effective tool to coordinate activities in the team effectively

- Improve the organization's ability to recruit and retain employees with good performance

- Maintain the stability of organizational performance

- Helping the organization's ability to sustain and adapt to environmental changes

- Increasing capacity for adaptation to environmental changes

- Make organizations more effective by creating social capital

According to (Novliadi, 2006) in (Cahyono, 2015) stated that the factors that influence OCB are quite complex and are related to one another. These factors are:

a) Organizational culture and climate;

(Permadi, 2009) in (Cahyono, 2015) stated that employees tend to take action beyond their responsibility if:

1) Feel satisfied with the job.

2) Receive attentive treatment from the supervisor.

3) Treated in a fair way by organization.

(Konovsky \& Pugh, 1994) used social exchange theory to argue that when employees are satisfied with their work, they will reciprocate. Retaliation from these employees includes a strong sense of belonging to organizations and behaviors such as organizational citizenship.

b) Personality and mood;

According to (Elanain, 2007), individual personality plays an important role in work behavior. Personality and mood have an influence on OCB behavior individually and in groups. Personality is a reality that can change. A positive mood will increase one's chances of helping others.In addition, according to (Purba \& Seniati, 2004), personality has a considerable influence on OCB. Researchers see from the cultural side of Indonesian employees who uphold the value of togetherness. It can be said that the more emotional the employee with the organization, the more likely it is to help colleagues and superiors in terms of completing tasks, preventing problems at work, the more likely it is to help the organization in total, by tolerating less ideal situations at work, care about the organization, and obey organization rules.

c) Organizational support;

(Shore \& Wayne, 1993) in (Cahyono, 2015) found that perceptions of organizational support (Perceived Organizational Support / POS) can be OCB predictor. Workers who feel that they are supported by the organization will provide feedback and reduce imbalances in the relationship by engaging in citizenship behavior.

d) Quality of superior and subordinate relationships;

(Permadi, 2009) in (Cahyono, 2015)revealed that a leader will have a positive view of his staff and the staff will feel that their leader provides support and motivation. This increases the trust and respect of subordinates to their superiors so that they are motivated to do more than their superiors expect. The superiors' willingness to use their authority to help their subordinates solve the problems faced by their subordinates in solving the problems. This is the most dominant factor in influencing OCB (Novliadi, 2006).

e) Working time;

(Sommer, Bae, \& Luthans, 1996) claimed that working time can function as a predictor of OCB because these variables represent a "measure" of the "investment" of employees in the organization. Employees who have worked for a long time in an organization will have a strong 


\section{International Journal of Business Management and Economic Review}

Vol. 4, No. 02; 2021

ISSN: 2581-4664

closeness and attachment to the organization. A long working period will also increase the selfconfidence and competence of employees in doing their jobs and generate positive feelings and behavior (Cahyono, 2015).

f) Gender;

(Permadi, 2009) in (Cahyono, 2015) found a significant difference between men and women in their level of OCB behavior, where women helped more than men. Women perceive OCB as part of their in-role behavior than men (Morrison, 1994). This suggests that women tend to internalize group expectations, a sense of belonging, and helpful activities as part of their work (Diefendorff, Brown, Kamin, \& Lord, 2002).

In this study, the indicators used to measure OCB behavior among employees were developed by (Mowday, Steers, \& Porter, 1979). The OCB indicators consist of (1). Employees always obey the rules even though they are not supervised, (2) Employees awareness to always behave honestly at work, (3) Employees are always willing to help other employees in dealing with problems and difficulties, (4) Employees are always willing to provide assistance to those around them, (5) Employees always pay attention to existing changes, (6) Employees always play an active role in the improvement and restructuring of the organization, (7) Employees do not like to complain at work, (8) Employees always maintain relationships to avoid interpersonal problems, (9) Employees always remind colleagues of their actions in preventing problems.

\subsection{Organizational Climate (Org. Climate)}

According to (Gelade \& Ivery, 2003) organizational climate is an intermediary factor for human resources and organizational performance. Progressive human resource practices will encourage a positive organizational climate, increasing the employee's welfare and motivation which leads to strengthening the performance of organizational units. Furthermore (Gelade \& Ivery, 2003) said that organizational climate is an interpretation of the work environment by the people in it, this opinion shows that the organizational climate is different from the work environment. The work environment is a physical factor, while the organizational climate is the psychological atmosphere of the people in the work environment. (Gelade \& Ivery, 2003) provided an example that changes in wage and promotion policies can be expected to change employees' perceptions of reward orientation and the possibility of equality and honesty, as well as the introduction of training programs as practices that often improve productivity, possibly having a positive effect on employee perceptions. about organizational support. The organizational climate will affect the cognitive (knowledge) and feelings of employees in the workplace.

(Steers, 1984) argued that there are at least 4 (four) components that determine an organizational climate, namely the organizational policy structure, technology, external environment, policies and management practices. Every organization has a different climate. (Lussier, 2016)revealed the organizational climate indicators include:

a) Structure is the level of coercion felt by employees because of structured rules and procedures.

b) Responsibility is the level of supervision imposed by the organization and felt by employees, where quality and supervision, direction, and guidance are received from superiors to subordinates.

c) Reward is the level of appreciation given to employees' efforts. Employees are rewarded according to their performance. 


\section{International Journal of Business Management and Economic Review}

Vol. 4, No. 02; 2021

ISSN: 2581-4664

d) Warmth relates to the level of employee satisfaction concerning other employees in the organization.

e) Support is support for employees in carrying out organizational tasks.

f) Organizational identity and loyalty are related to feeling proud of being in the organization and the loyalty shown during the work period.

g) Risk relates to employees being given the opportunity to take risks in carrying out their duties as a challenge.

\subsection{Organizational Commitment (Org. Commitment)}

(Mowday, Porter, \& Steers, 2013) defined work commitment as the relative strength of individual identification and engagement with work organizations. Meanwhile (Guay, Choi, Oh, $\&$ Mitchell, 2015) views work commitment as a value orientation towards work which shows that individuals really think about their work, for example work provides life satisfaction, and work gives status to individuals.

Commitment will make the organization more productive (Luthans, 2012). A strong organizational commitment within the individual will cause individuals to try to achieve organizational goals according to organizational interests (Angle \& Perry, 1981); (Mowday et al., 1979) in (Coryanata, 2014). They will have a positive view and try to do their best for the benefit of the organization. High commitment makes individuals care about the fate of the organization and strives to make the organization a better direction. The effect of participation in the budgeting process on performance will be high if the leader has a high commitment. On the other hand, the effect of participation in the budgeting process on performance will be low if the organizational commitment of the leadership is low (Coryanata, 2014).

According to (Soekidjan, 2009) indicators of commitment behavior can be seen in employees, namely:

1. Making adjustments, in a way that fits in the organization and does things expected, respects organizational norms, and complies with applicable regulations.

2. Be loyal, by helping others, respecting and accepting things that are considered important by superiors, being proud to be part of the organization, and caring about the image of the organization.

3. Support actively, by acting in support of the mission to meet the needs/mission of the organization and adapt to the mission of the organization

4. Making personal sacrifices, by placing the interests of the organization above personal interests, making sacrifices in terms of personal choice, and supporting decisions that benefit the organization even though these decisions are not favored.

\subsection{Research Hypothesis}

Based on the literature, this study provided seven hypotheses that build the research model. Sometimes the names for each variable were shortened to facilitate writing, namely organizational climate was abbreviated as Org. Climate, organizational commitment was shortened to Org. Commitment, organizational citizenship behavior was shortened to OCB, and employee performance was shortened to EP. The hypotheses were as follows.

$\mathrm{H} 1$ :Org. Climate affects OCB;

$\mathrm{H} 2$ :Org.Commitment affects OCB; 
International Journal of Business Management and Economic Review

Vol. 4, No. 02; 2021

ISSN: 2581-4664

H3 :Org.Climate has no effect on EP;

$\mathrm{H} 4$ :Org.Commitment affects EP;

H5 :OCBaffectsEP;

H6 : OCB mediates the influence of Org.Climate on EP, and;

$\mathrm{H} 7$ : OCB mediates the influence of Org.Commitment on EP.

\section{RESEARCH METHOD}

\subsection{Population and Research Sample}

The population in this study was all employees at the Secretariat Office of the Pidie Jaya District Government, Indonesia, totaling 221 employees consisting of 63 permanent employees and 158 contract employees.

Because all members of the population were taken as respondents, the method used in this study was total population sampling. The total population sampling method was carried out because the population was relatively small so that it was possible to be reached and interviewed as well as meeting the requirements for the number of samples used in the analysis method using structural equation modeling (SEM) (Hair, Hult, Ringle, \& Sarstedt, 2016).

\subsection{Data Collection Technique}

The data that was collected are:

1. Primary data, collected directly through a questionnaire consisting of question items that are distributed to employees of the Regional Secretariat of the Pidie Jaya District Government.

2. Secondary data, obtained from the documentation of the Regional Secretariat of the Pidie Jaya District Government.

\subsection{Data Analysis Method}

Data analyzed using Structural Equation Modeling (SEM). (F. Hair Jr, Sarstedt, Hopkins, \& G. Kuppelwieser, 2014) explained that the SEM equation model is a set of statistical techniques that allow testing a series of relatively "complicated" relationships simultaneously. Before testing the hypothesis, confirmatory factor analysis (CFA). Confirmatory factor analysis was used to confirm the measurement model with the same data.

\section{RESULT}

Testing with Structural Equation Modeling (SEM) analysis wasdonethroughtwo stages, wherein the first stageusedthe Confirmatory Factor Analysis (CFA) and in the second stage used the Full Structural Equation Model (Ghozali, 2017). The first stage has been done, and the second stage has been provided (with its remaining selected indicators), as follows. 
International Journal of Business Management and Economic Review

Vol. 4, No. 02; 2021

ISSN: 2581-4664

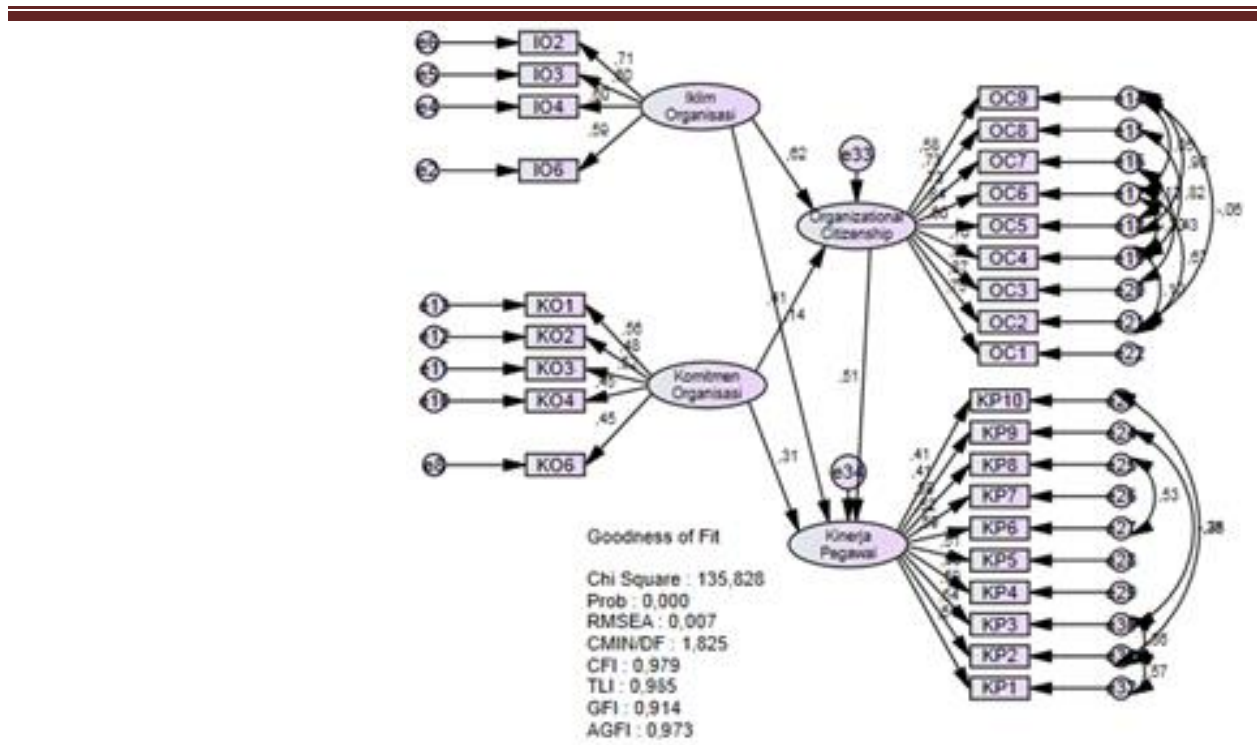

Figure 1.Structural Equation Model (SEM) Result

This SEM provides the Critical Ratio (CR) and probability (P) then comparing it with the required statistical limits, which are above 1.96 for the $C R$ value and below 0.05 for the P-value.

Table 1. Research hypothesis test -Regression Weights: (Group number 1 - Default model)

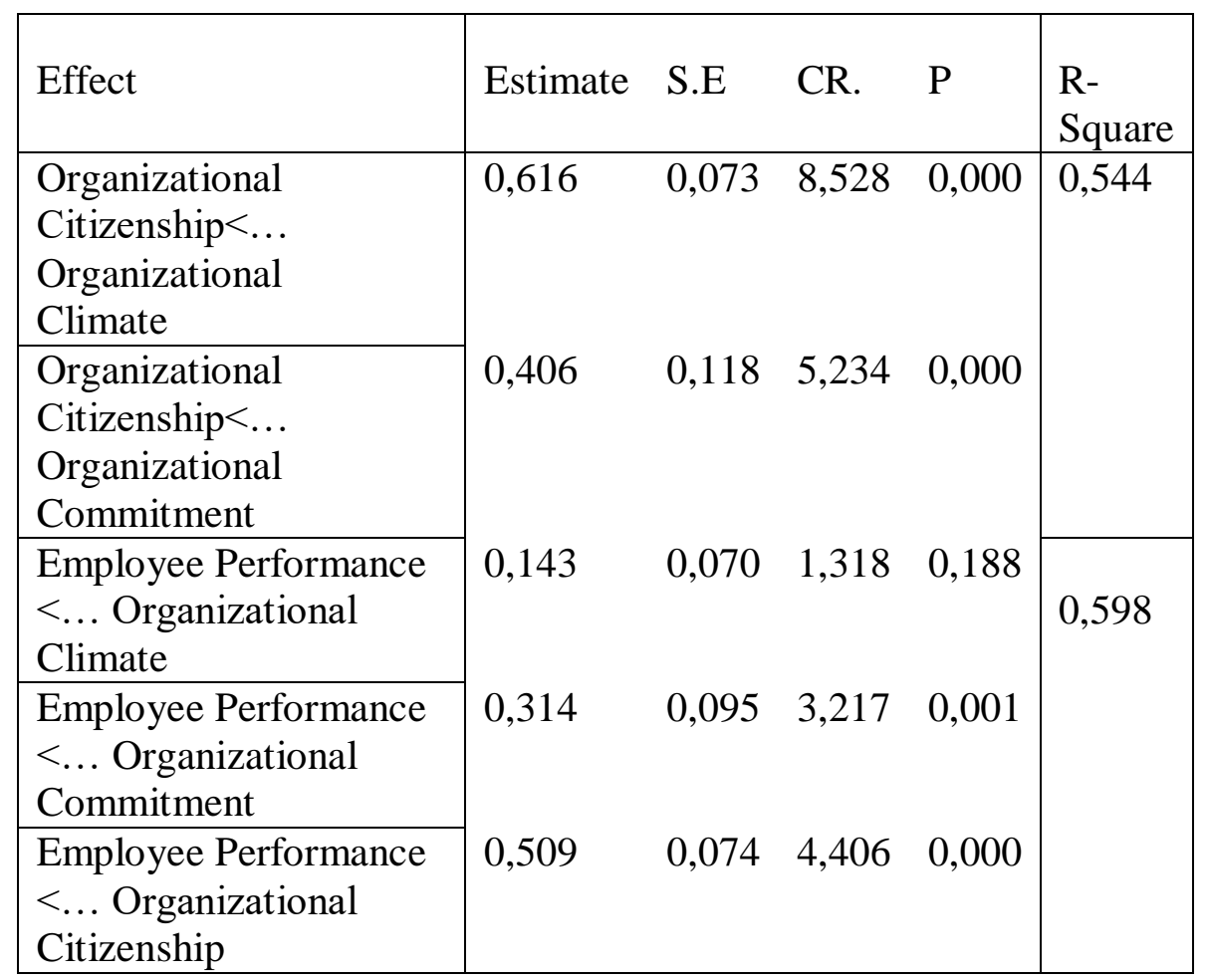


International Journal of Business Management and Economic Review

Vol. 4, No. 02; 2021

ISSN: 2581-4664

Source: Data processed through SEM (2020)

Based on the results of SEM analysis in Table 4.11 and statistical equations (1) and (2), the following results can be formulated:

$\mathrm{OCB}=0.616$ Org.Climate +0.406 Org. Commitment

$\mathrm{EP}=0.143$ Org. Climate + 0.314 Org.Commitment+ 0.509 OCB

Based on Table 1, the $\mathrm{R}$ square value for the influence of Org.Climate and Org.Commitment on OCB is 0.544. This shows that the variables of Org.Climate and Org.Commitment are able to explain the OCB variable by $54.4 \%$, while the remaining $45.6 \%$ is explained by other variables outside of research.

The R square value for the influence of Org.Climate, Org.Commitment, and OCB on EP is 0.598 . This shows that the variables of Org.Climate, Org.Commitment, and OCB are able to explain the EP variable by $59.8 \%$, while the remaining $40.2 \%$ is explained by other variables outside the research.

\section{$\mathrm{H1}$ :Org.ClimateInAffectingOCB}

The influence of Org.Climate on OCB obtained a CR value of 8,528 with a significance level of 0,000 . Thus, it can be concluded that Org.Climate affects the increase of OCB. The value of the influence of Org.Climate on OCB is 0.616 or $61.6 \%$. This indicates that the better the Org.Climate will have a positive and real effect on the improvement of employee OCB.

\section{$\mathrm{H} 2$ :Org.CommitmentInAffectingOCB}

The Effect of Org.Commitment on OCB obtained a CR value of 5.234 with a significance level of 0.000 . Thus, it can be concluded that Org.Commitment affects the increase of OCB. The magnitude of the influence of Org.Commitment on OCB is 0.406 or $40.6 \%$. This indicates that the higher the Org.Commitment level, the more OCB of employees will be.

\section{H3 :Org.ClimateInAffectingEP}

The influence of Org.Climate on EP obtained a CR value of 1.318 with a significance level of 0.188. Thus, it can be concluded that Org.Climate does not affect EP.

\section{H4 :Org.CommitmentInAffectingEP}

The influence of Org.Commitment on EP obtained a CR value of 3.217 with a significance level of 0.001. Thus, it can be concluded that Org.Commitment has an influence on improving EP. The amount of influence of Org.Commitment on EP is 0.314 or $31.4 \%$. This indicates that the higher the level of Org.Commitment, the more EP will be.

\section{H5 :OCBInAffectingEP}

The influence of OCB on EP obtained a CR value of 4.406 with a significance level of 0.000. Thus, it can be concluded that OCB affects EP. The magnitude of the influence of OCB on EP is 0.509 or $50.9 \%$. This indicates that the higher OCB will have a direct effect on improving EP.

\section{H6 :Org.ClimateInAffectingEP through OCB}

Testing the mediating effect of the Org.Climate variable on EP can be explained as follows 
International Journal of Business Management and Economic Review

Vol. 4, No. 02; 2021

ISSN: 2581-4664

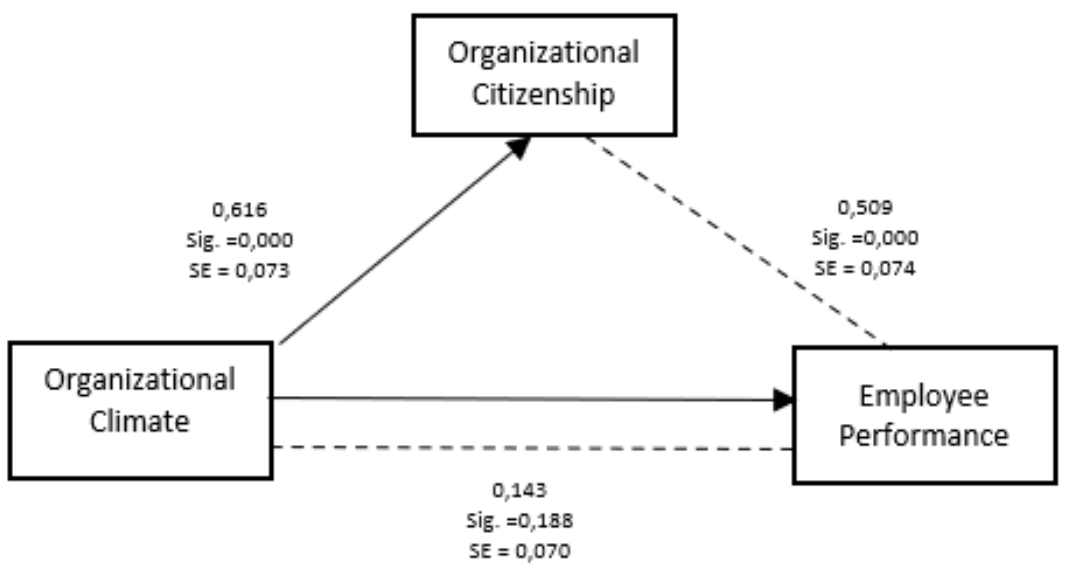

Figure 2.Testing the Mediating Effect of Org.Climate on EP through OCB

From the Sobel test calculation, the results are 5,331 and significant at $\alpha=0,000$. Thus, OCB acts as a variable that mediates Org.Climate and EP. Because OCB has a significant effect and acts as a mediating variable, and Org.Climate does not have a significant effect on EP, therefore the role of OCB in mediating the relationship between Org.Climate and EP is as a full mediation.

Based on Figure 2, the Sobel value can be seen in Table 2 as follows:

Table 2.Sobel Test Result of The Effect of Org.Climate on EP ThroughOCB

\begin{tabular}{|c|c|c|c|c|c|}
\hline \multicolumn{2}{|r|}{ Input: } & \multicolumn{2}{|r|}{ Test statistic: } & Std. Error: & p-value: \\
\hline a & 0.616 & Sobel test: & 533153004 & 0.05880938 & $1 \mathrm{e}-7$ \\
\hline$b$ & 0.509 & Aroian test: & 530917888 & 0.05905697 & $1.1 \mathrm{e}-7$ \\
\hline$s_{3}$ & 0.073 & Goodman test: & 5.35416588 & 0.05856076 & $9 e-8$ \\
\hline & 0.074 & Reset all & & Calculate & \\
\hline
\end{tabular}

\section{H7 :Org.CommitmentInAffectingEP through OCB}

The results showed that testing the mediating effect of the Org.Commitment variable on $\mathrm{OCB}$ can be explained as follows: 
International Journal of Business Management and Economic Review

Vol. 4, No. 02; 2021

ISSN: 2581-4664

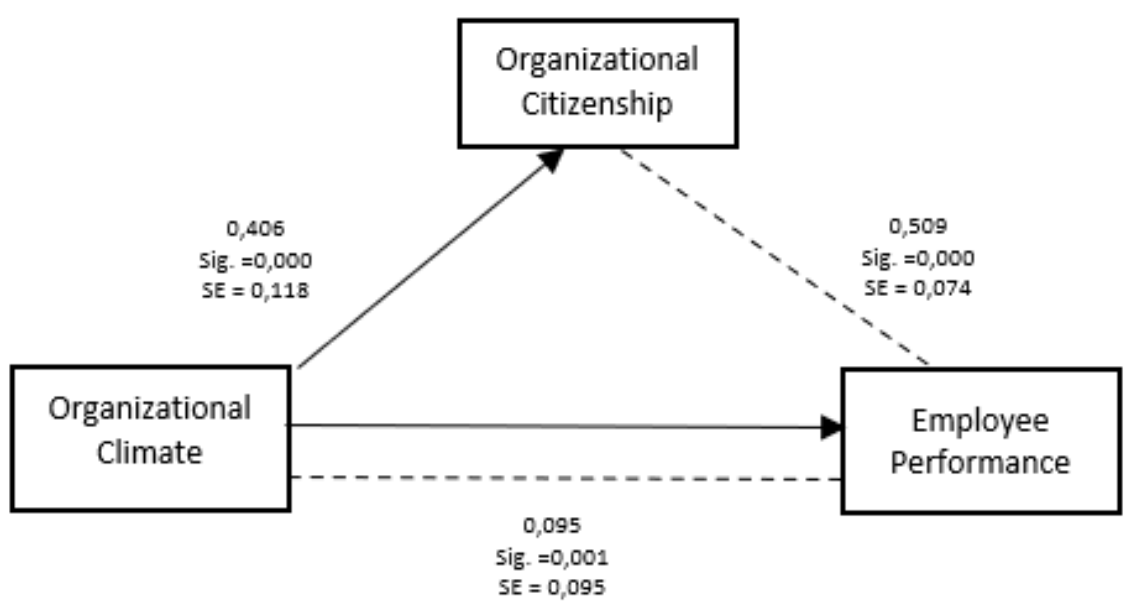

Figure 3.Testing the Mediating Effect of Org.Commitment on EP through OCB

From the Sobel test results, the results are 3.6077 and significant at $\alpha=0.002$. Thus, OCB acts as a variable that mediates Org.Commitment and EP. Because OCB has a significant effect and acts as a mediating variable, Org.Commitment has a significant effect on EP, therefore, the role of OCB in mediating the relationship between Org.Commitment and EP is partial mediation.

Based on Figure 3, the Sobel value can be seen in Table 3 as follows:

Table 3.Sobel Test Result of Org.Commitment on EP ThroughOCB

\begin{tabular}{|c|c|c|c|c|}
\hline Input: & & Test statistic: & Std. Error: & D-value: \\
\hline a 0.406 & Sobel test: & 307716947 & 0.06715717 & 0.00208976 \\
\hline b 0.509 & Arolan test: & 305148328 & 0.06772247 & 0.00227714 \\
\hline $5,0.118$ & Goodman test: & 3.10351542 & 0.06658707 & 0.00191236 \\
\hline 500074 & Reset al & & Calculate & \\
\hline
\end{tabular}

\section{CONCLUSION}

The result shows that Organizational climate affects OCB; Organizational Commitment affects OCB; Organizational Climate does not affect Employee Performance; Organizational Commitment affects Employee Performance; OCB affects Employee Performance; OCB fully mediates the influence of Organizational Climate on Employee Performance, and; OCB partially mediates the influence of Organizational Commitment on Employee Performance. The findings of this research can contribute to the development of knowledge, especially in the field of management on the object of government employees. This model of improving the performance of government employees can be relied on by making improvements to the organizational climate that will take advantage of OCB as a mediator in improving their performance, and strengthen organizational commitment that is able to influence their performance both directly and through OCB. Further researchers are advised to further develop government employee performance models like this by testing them with variables such as organizational culture and 


\section{International Journal of Business Management and Economic Review}

Vol. 4, No. 02; 2021

ISSN: 2581-4664

talent management.

For the practice, this can be a reference for practitioners to re-set their strategy in improving their employee performance. For the Pidie Jaya Regional Secretariat, several suggestions can be given. In the Organizational Climate variable, the support was found as the most influential indicator andin the Organizational Commitment variable, the most influential indicator is the sense of belonging to the organization. So regarding that two indicators, the organizationneeds to improve in the strategyto more focus on support to employees by considering all aspects related, and also to create the sense of belonging of the employee to the organization.

\section{REFERENCES}

Albrecht, S. L. (2010). Research and Practice. Handbook of Employee Engagement Perspective. In Issues. UK: MGP Books Group. Cheltenham, UK・ Northampton, MA, USA.

Aldag, R., \& Reschke, W. (1997). Employee Value Added: Measuring Discretionary Effort and Its Value to the Organization.

Angle, H. L., \& Perry, J. L. (1981). An Empirical Assessment of Organizational Commitment and Organizational Effectiveness. Administrative Science Quarterly, 26(1), 1-14.

Aspan, H., Wahyuni, E. S., Effendy, S., Bahri, S., Rambe, M. F., \& Febrian, B. S. (2019). The Moderating Effect of Personality on Organizational Citizenship Behavior: the Case of University Lecturers. International Journal of Recent Technology and Engineering (IJRTE), $8(2 \mathrm{~S}), 412-416$.

Buleleng, K. (2019). Teori Kinerja Pegawai. Retrieved January 25, 2020, from bulelengkab.go.id website: https://www.bulelengkab.go.id/detail/artikel/teori-kinerja-pegawai-15

Cahyono, B. C. (2015). Pengaruh Budaya Organisasi, Kepemimpinan Dan Stress Kerja Terhadap Organizational Citizenship Behavior (OCB) Dengan Kepuasan Kerja Sebagai Variabel Intervening Pada Tenaga Medis Rsu Kaliwates Kabupaten Jember. Univeristas Jember.

Chang, C.-C., Tsai, M.-C., \& Tsai, M.-S. (2011). The Organizational Citizenship Behaviors and Organizational Commitments of Organizational Members Influences the Effects of Organizational Learning. International Journal of Trade, Economics and Finance, 2(1), 6166.

Coryanata, I. (2014). Pelimpahan Wewenang dan Komitmen organisasi Dalam Hubungan Antara Partisipasi Penyusunan Anggaran dan Kinerja Managerial. Makalah Simposium Nasional Akuntansi (SNA) VII.

Diefendorff, J., Brown, D., Kamin, A., \& Lord, B. (2002). Examining the Roles of Job Involvement and Work Centrality in Predicting Organizational Citizenship Behaviors and Job Performance. Journal of Organizational Behavior, 23, 93-108. https://doi.org/https://doi.org/10.1002/job.123 


\section{International Journal of Business Management and Economic Review}

Vol. 4, No. 02; 2021

ISSN: 2581-4664

Elanain, H. A. (2007). Relationship between Personality and Organizational Citizenship Behavior: Does Personality Influence Employee Citizenship? International Review of Business Research Papers, 3(4), 31-43.

F. Hair Jr, J., Sarstedt, M., Hopkins, L., \& G. Kuppelwieser, V. (2014). Partial least squares structural equation modeling (PLS-SEM) An emerging tool in business research. European Business Review, 26(2), 106-121.

Gelade, G. A., \& Ivery, M. (2003). The impact of human resource management and work climate on organizational performance. Personnel Psychology, 56(2), 383-404. https://doi.org/https://doi.org/10.1111/j.1744-6570.2003.tb00155.x

Ghozali, I. (2017). Model Persamaan Struktural, Konsep dan Aplikasi dengan Program AMOS 24 Update Bayesian SEM (Edisi 7). Semarang: Badan Penerbit Universitas Diponegoro.

Gibson, J., Ivancevic, J., \& Konopaske, R. (2012). Organizations: Behavior, Structure, Processes (14th ed.). New York: Mc Graw Hill.

Guay, R. P., Choi, D., Oh, I.-S., \& Mitchell, M. (2015). Why People Harm the Organization and Its Members: Relationships among Personality, Organizational Commitment, and Workplace Deviance. Human Performance, 29(1), 1-36. https://doi.org/10.1080/08959285.2015.1120305

Hair, J. F., Hult, G. T. M., Ringle, C., \& Sarstedt, M. (2016). A Primer on Partial Least Squares Structural Equation Modeling (PLS-SEM) (2nd ed.). New York: SAGE Publications, Inc.

Haritha, K., \& Subrahmanyam, D. S. (2013). Organisational Climate: An Empirical Investigation in PennaCement Industries Limited ( PCIL ) 1. International Journal of Business and Management Invention, 2(12), 12-20.

Huang, J., Wang, L., \& Xie, J. (2014). Leader-Member Exchange and Organizational Citizenship Behavior: the Roles of Identification with Leader and Leader's Reputation. Social Behavior and Personality An International Journal, 42(10), 1699-1712. https://doi.org/https://doi.org/10.2224/sbp.2014.42.10.1699

Iskandar, Hutagalung, D. J., \& Adawiyah, R. (2019). The Effect Of Job Satisfaction And Organizational Commitment Towards Organizational Citizenship Behavior (Ocb): A Case Study On Employee Of Local Water Company tirta Mahakam Kutai Kartanegara Indonesia. Jurnal EKonomi Bisnis Dan Kewirausahaan, 18(3).

Konovsky, M. A., \& Pugh, S. D. (1994). Citizenship Behavior adn Social Exchange. Academy of Management Journal1, 37(3), 656-669. https://doi.org/10.2307/256704

Lussier, R. (2016). Human Relations in Organizations: Applications and Skill Building (Irwin Management) (10th ed.). New York: McGraw-Hill.

Luthans, F. (2012). Organization Behavior An Evidence-Based Approach. In Organizational Behavior: An edivence-Based Approach. Boston: McGraw-Hill.

Margaretha, M., \& Wicaksana, A. (2020). The Relationship between Person Organization Fit Toward Organizational Commitment and Organizational Citizenship Behavior: Experiences 


\section{International Journal of Business Management and Economic Review}

Vol. 4, No. 02; 2021

ISSN: 2581-4664

from Student Activity Organization Members. International Journal of Management Science and Business Administration, 6(3), 43-49. https://doi.org/10.18775/ijmsba.18495664-5419.2014.63.1004

McShane, S., \& Glinow, M. A. Von. (2010). Organizational Behavior (5th ed.). New York: Mc Graw Hill.

Merentek, G. C., Adolfina, \& Trang, I. (2018). Pengaruh Iklim Organisasi, Komitmen Organisasi dan Organizational Citizenship Behaviour Terhadap Kinerja Karyawan PT. PLN (Persero) Area Manado. Jurnal EMBA, 6(4), 2648 - 2657. https://doi.org/https://doi.org/10.35794/emba.v6i4.21046

Mohammad, J., Habib, F. Q., \& Alias, M. A. (2011). Job satisfaction and organisational citizenship behaviour: An empirical study at higher learning institutions. Asian Academy of Management Journal, 16(2), 149-165.

Morrison, D. E. (1994). Psychological contracts and change. Human Resource Management, 33(3). https://doi.org/https://doi.org/10.1002/hrm.3930330305

Mowday, R. T., Porter, L. W., \& Steers, R. M. (2013). Employee-organization linkages: The psychology of commitment, absenteeism, and turnover. Retrieved from https://books.google.co.id/books?hl=en\&lr=\&id=f_FFBQAAQBAJ\&oi=fnd\&pg=PP1\&dq= The+Psychology+of+Commitment,+Absenteeism,+and+Turnover\&ots=GjRzL7Mg_3\&sig $=$ Rr9BvXL6mJBF4VJc8x9PBPay6ZY\&redir_esc $=y \# v=$ onepage \&q=The Psychology of Commitment $\% 2 \mathrm{C}$ Absenteeism\%2C and $\mathrm{T}$

Mowday, R. T., Steers, R. M., \& Porter, L. W. (1979). The measurement of organizational commitment. Journal of Vocational Behavior, 14(2), 224-247. https://doi.org/https://doi.org/10.1016/0001-8791(79)90072-1

Muttaqin, N. I., Djumadi, \& Noor, M. (2013). Pengaruh Motivasi Kerja Terhadap Pelayanan Publik Di Kantor Camat Tenggarong Kabupaten Kutai Kartanegara. EJournal Administrative Reform, 1(1), 246-256.

Novliadi, F. (2006). Organizational Citizenship Behavior Karyawan Ditinjau Dari Persepsi Terhadap Kualitas Interaksi Atasan-Bawahan Dan Persepsi Terhadap Dukungan Organisasional. Psikologia, 2(1), 39-46.

Organ, D. W. (2015). Organizational Citizenship Behavior (Second). Amsterdam: Elsevier Ltd.

Organ, D. W., Podsakoff, P. M., \& MacKenzie, S. B. (2006). Organizational Citizenship Behavior: Its Nature, Antecedents, and Consequences. Retrieved from http://sk.sagepub.com/books/organizational-citizenship-behavior

Paramita, E. (2018). Pengaruh Iklim Organisasi Terhadap Organizational Citizenship Behaviour serta Dampaknya Terhadap Kinerja Karyawan IKIP PGRI Pontianak. Equator Journal of Management and Entrepreneurship, 6(3), 1-22.

Permadi. (2009). Perilaku Organisasi. Yogyakarta: Gajah Mada University.

Podsakoff, P. M., Ahearne, M., \& MacKenzie, S. B. (1997). Organizational Citizenship Behavior 


\section{International Journal of Business Management and Economic Review}

Vol. 4, No. 02; 2021

ISSN: 2581-4664

and the Quantity and Quality of Work Group Performance. Journal of Applied Psychology, 82(2), 262-270.

Purba, E. D., \& Seniati, A. N. L. (2004). Pengaruh kepribadian dan komitmen organisasi terhadap. Makara, Sosial Humaniora, 8(3), 105-111.

Purwanti, D., \& Nurhayati, M. (2016). Pengaruh Iklim Organisasi dan Tipe Kepribadian Terhadap Stres Kerja dan Perilaku Kewargaan (Studi pada Karyawan Klinik Laboratorium Prodia Cabang Menteng, Jakarta). Jurnal Manajemen, XX(2), 293-309.

Robbins, S. P., \& Judge, T. A. (2008). Perilaku organisasi, edisi bahasa indonesia. In alih bahasa D. Angelica (Ed.), Jakarta: PT. Indeks Kelompok Gramedia (Edisi 12). Jakarta: Salemba Empat.

Robbins, S. P., \& Judge, T. A. (2014). Buku Perilaku Organisasi Buku 2 (Edisi ke-1; alih bahasa D. Angelica, Ed.). Salemba Empat.

Shore, L. M., \& Wayne, S. J. (1993). Commitment and employee behavior: Comparison of affective commitment and continuance commitment with perceived organizational support. $\begin{array}{lllll}\text { Journal of } & \text { Applied } & \text { Psychologyl, } & 78(5), & \text { 774-780. }\end{array}$ https://doi.org/https://doi.org/10.1037/0021-9010.78.5.774

Soekidjan. (2009). Manjaemen Sumber Daya Manusia. Jakarta: Bumi Aksara.

Sommer, S. M., Bae, S.-H., \& Luthans, F. (1996). rganizational Commitment Across Cultures: The Impact of Antecedents on Korean Employees. Human Relations, 49(7), 977-993. https://doi.org/https://doi.org/10.1177/001872679604900705

Steers, R. M. (1984). Efektifitas organisasi (kaida perilaku) (4th Ed; M. Jamin, Ed.). Jakarta: Erlangga.

Suzana, A. (2017). Pengaruh Organizational Citizenship Behavior (OCB) Terhadap Kinerja Karyawan (studi di : PT. Taspen (persero) Kantor Cabang Cirebon). Jurnal Logika, XIX(1), 42-50.

Takeuchi, R., Bolino, M. C., \& Lin, C.-C. (2015). Too Many Motives? The Interactive Effects of Multiple Motives on Organizational Citizenship Behavior. Journal of Applied Psychology, 100(4), 1239-1248. https://doi.org/http://dx.doi.org/10.1037/apl0000001

Vijayabanu, C., Anand, V. V., Kumar, V. S., \& Therasa, C. (2017). Perceived Organization Climate and Work Commitment in Indian Private Manufacturing Sector, International Journal of Economic Research. International Journal of Economic Research, 14(8), 443450 .

Wirawan. (2012). Evaluasi Kinerja Sumber Daya Manusia: Teori, Aplikasi, dan Penelitian. Jakarta: Salemba Empat.

Yukl, G. (2010). Leadership in Organizations. In The British Journal of Psychiatry (Seventh Ed, Vol. 112). https://doi.org/10.1192/bjp.112.483.211-a 